110 Наукові записки ХНПУ ім. Г.С. Сковороди. Літературознавство, 2020, вип. 1(95)

УДК 82.0

А.О. Ліпісівіцька

\title{
ХУДОЖНЯ КАРТИНА СВІТУ: ПОСТАНОВА ПРОБЛЕМИ НА ПЕРЕТИНІ МЕТОДОЛОГІЧНИХ ПЛОЩИН
}

\section{Вступ}

Світ, який нас оточує, є дійсністю, цілісною у своїй ідеальності. Ідеальний образ дійсності вимальовується нашою свідомістю у картину, яка допомагає осягнути і пізнати естетику навколишнього світу, що знаходить своє відображення у конкретних сферах людської діяльності, передусім у художній творчості та мистецтві. Особливість художньої картини світу полягає у суб'єктивному ставленні митця, автора твору, до об'єктивної реальності і до людини як суб'єкта й об'єкта художнього творення. Зображений (омовлений у літературі як мистецтві слова) художній світ постає перед нами в безлічі поетичних образів, зумовлених багатовіковою історією і культурою народів, різноманітними мистецькими традиціями.

Художня картина світу існує не лише у просторі художнього i, зокрема, літературного твору. Дослідники в галузі літератури описують, теоретично моделюють, інтерпретують іï у площині перетину різних методологій, щоб простежити і проаналізувати певні зв'язки й концепти, які народжуються і взаємодіють між собою на текстуальних та смисленнєвих рівнях твору.

Метою статті $є$ аналіз і обгрунтування концептуального поняття «художня картина світу» з опорою на теоретико-літературні ідеї О.О. Потебні, методологічні настанови філософської герменевтики, формальної і міфологічної літературних шкіл.

\section{Методи дослідження}

Для реалізації мети слугують загальнонаукові методи аналізу теоретико-методологічних джерел, узагальнення, синтезу, порівняння і мисленнєвого експерименту. 


\section{Огляд літератури}

У статті здійснюється концептуалізація поняття «художня картина світу» 3 опорою на класичні наукові праці, важливі в контексті розвитку літературознавчої методології, а саме роботи мовознавців В. Гумбольдта $(1836,1907)$ і Ф.М. Мюллера $(1870,1875)$, «Теоретичну поетику» О.О. Потебні $(1905,1990)$ та їі актуалізацію у працях I. Фізера (1996), роботи засновника філософської герменевтики В Дільтея $(1927,2013)$, представників формального літературознавства В.Б. Шкловського $(1929,1990)$, Б.М. Ейхенбаума (1927), дослідника теоретичної фольклористики та поетики міфу С.М. Мелетинського (2000).

\section{Результати і дискусії}

Літературознавчі методи почали зароджуватись у XIX ст., і вже тоді були зроблені перші кроки до їх взаємодії. Так, Олександр Потебня - видатний український філолог і літературознавець - написав фундаментальні праці, відголоски яких перегукуються в постулатах різних літературознавчих шкіл. Його праці стали джерелом численних лінгвістичних й літературознавчих досліджень, що дає можливість грунтовно дослідити і відтворити художню картину світу, створену і в межах окремого літературного твору, і в художньому просторі кожної літературної епохи.

Художня картина світу починає вибудовуватися у реципієнта в той момент, коли він «дотикається» до твору, читає його. Читач зустрічається спершу із зовнішньою формою слова - звуком, який гармонійно проникає у його свідомість й об'єктивується у буквеному слові, що сприймається вже іншим естетичним органом чуття зором. Слово й звук, ставши одним цілим, утворюють неподільний образ, завдяки якому крізь нетрі нашої підсвідомості проривається зміст - думка, ідея, яку ми пізнаємо. Образ виконує функцію пензля, інструменту для зображення художнього світу твору. Побудова картини світу - це послідовний і одночасний процес сприйняття та пізнання: людська свідомість зустрічається спершу із зовнішньою формою поетичного твору, сприймає іiі і переходить до стадії чуттєвого пізнання, сприймаючи створений двокомпонентний образ і думку, 
яку він містить. Таким чином, картина світу $є$ результатом пізнання художнього світу твору. «Людина, - зауважував I. Фізер, - розповідає про реальну дійсність послідовно, бо вона сприймає її послідовно» (Фізер, 1996: 30). Керуючись своїми органами чуття, вона споглядає дійсність з різних точок зору, не охоплюючи їі цілісно, адже цілісність - абстрактна, це певна ідеальна конструкція, яку неможливо осягнути. О. Потебня вважав: «Розмірковування (над твором. - А.Л.) $\epsilon$ послідовний ряд думок, що приводить до певного висновку» (Потебня, 1905: 5). Даний висновок і являє собою опис художньої картини світу, відображену в літературному творі.

Художня картина світу невідривно пов'язана 3 природною картиною світу, і саме мова є посередником між цими двома світами, вона допомагає людині в процесі художнього пізнання встановити зв'язки зі своєю дійсністю і завдяки такому синтезу вибудувати поетичну картину. В. Гумбольдт стверджував: «Проза або поезія рухаються від дійсності до чогось такого, що їй не належить. Поезія сприймає дійсність у їі чуттєвій феноменальності так, як вона зовнішньо і внутрішньо усвідомлюється нами... Вона поєднує ці чуттєві феномени 3 творчою уявою і через них веде нас до бачення мистецьки ідеальної цілісності» (Humboldt, 1836: 193).

Поетичність художнього твору базується на образності його мови, крізь яку проступає сутність літературного твору. Образ є об'єктивною дійсністю поетичного твору. Він не зазнає перетворень під час сприйняття, змінюється утім його значення - щоразу, коли образ сприймається по-новому однією й тією ж людиною, а тим більше іншою. «В поезії, - вважав Потебня, - образ незрушний, значення змінне, визначуване лише в кожному окремому випадку, а в ряді випадків - безмежне» (Потебня, 1905: 101). Відповідно, художня картина світу - це винятково суб'єктивне явище. Незмінною залишається лише створювана єдиним суб' єктом - художником - авторська картина світу. Під час кожного наступного зіткнення з іншими суб'єктами, які проникають у сферу художнього світу, картина піддається деяким трансформаціям, які відбуваються на рівні значень, отриманих ззовні, хоча глибинно вона залишається цілісним 
неподільним утворенням з усією міфологічністю свого буття. Це підтверджується також спостереженнями В. Гумбольдта, який вважав, що «у певне слово одна людина ніяк не може вкладати той самий зміст, що й інша... Всяке розуміння є водночас нерозумінням, усяка згода в думках і почуттях так само є незгодою» (Humboldt, 1907: 545).

Зміст, розуміння, герменевтика художнього твору відсилають нас до міфологічного світу, який, по своїй суті, є реальністю, мова якої відійшла в забуття. О. Потебня, звертаючись до праць німецького мовознавця Ф.М. Мюллера, описує міфологію в контексті мовознавства і дає щедре підгрунтя для аналізу художньої картини світу 3 точки зору міфології. Мюллер тлумачив міфологію як «мову у стані самозабуття» (Müller, 1870: 146-147), як «стародавню мову, яка виходить за рамки свого першого значення» (Müller, 1870: 480). Виходячи зі спостережень Потебні про думку і слово, мову і твір, можна зауважити, що мова - це прозорий купол, яким огорнутий художній світ твору, і неможливо потрапити у нього, не пройшовши крізь матерію, яка ніби поглинає нас. Ми опиняємось у світі мови, світі слів, якими виражені поетичні образи, а кожен образ, як і кожне слово, це новий міф, за яким приховане забуте століттями висхідне значення пізнаваних об'єктів. Наша суб'єктивна думка спрямовує свою інтенцію на об'єкт і тим часом відволікається від свого суб'єктивного начала, та лише коли ми його усвідомлюємо, то починаємо розуміти суб'єктивність слів, шукати першопочаткові значення, надані їм реальними особами реального світу. Знання природного світу явищ, які реально існують, накладається на формальний світ мови, і в результаті таких метаморфоз народжується художня картина світу, яка поєднує у собі водночас реальну і фіктивну дійсність, природу і мистецтво. I неможливо теоретично осягнути повної картини, якщо ми не володіємо вихідним знанням, яке ховається у давно забутих, але все ще живих смислах словесних образів (Потебня, 1990).

Дослідження художньої картини світу продовжимо, увійшовши у методологічну площину Вільгельма Дільтея - засновника філософської герменевтики i представника духовно-історичної 
літературознавчої школи. Дільтей вводить в теорію літератури тріаду понять пережсивання - вираження - розуміння, яка складає основу герменевтичної теорії наук. Ї̈̈ можна співставити і порівняти 3 тріадою Потебні зовнішня форма - внутрішня форма - значення. Дефініції, наведені німецьким дослідником, представляють інтерпретацію людського світу з його двома крайніми полюсами - біхевіоризмом і картезіанством (Дильтей, 2000).

Тобто людський світ, що підтверджуються також думками Потебні, існує на перетині інстинктивного світу природи й одухотвореного світу культури, i, звичайно ж, ця реалія знаходить своє відображення у художньому світі літературних творів, адже будь-яка інтерпретація є суб'єктивною перспективою усвідомлення певного явища чи об'єкта. У цьому випадку це усвідомлення втілення життя людського роду в окремому людському індивіді, усвідомлення, до якого приходить автор, а згодом і читач. Зазирнемо глибше в естетичну триєдність, компоненти якої відтворюють шлях до цілісного зображення художньої і природної картин світу.

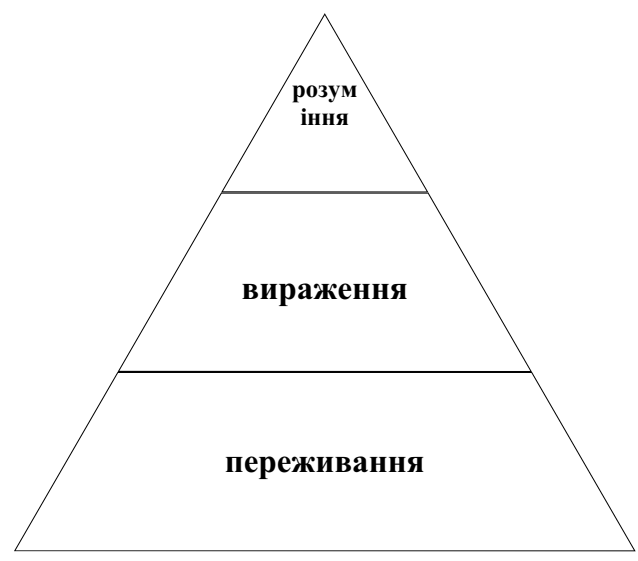

Рис. 1. Тріада понять В. Дільтея.

Перший елемент - переживання - $є$ первинним джерелом, 3 якого ми черпаємо увесь життєво-практичний досвід. Це те, що ми 
відчуваємо, споглядаючи певний об'єкт, асоціації, що виникають у нас під час споглядання і втілюються на паралельній осі вираження. В. Дільтей вважав, що переживання існують до тих пір, поки знаходять своє вираження в інтерсуб'єктивних артикуляціях, тобто в діях, загальнозрозумілих для кожного окремого індивіда, адже мають спільне першоджерело. Взаємозв'язок між переживанням і вираженням у конкретній дійсності полягає в розумінні, в значеннях, які $є$ частинами стосовно цілого життєвого процесу. У значеннях приховані культурні смисли, якими мають бути оформлені переживання, інакше втрачається естетичність окресленої тріади, а разом 3 нею й естетичність людського світу (Дильтей, 2000).

Культурний світ навколо нас, створений природою і довершений мистецтвом, є об'єктом пізнання людської свідомості, а сам процес пізнання світу, за Потебнею, невідривно пов'язаний з мовою. Цю думку підтримує й Вільгельм Дільтей, який вважає мову початковим способом артикуляції життя. Він стверджує, що «єдино лише в мові людське нутро набуває свого повного, вичерпного, об'єктивно зрозумілого вираження» (Dilthey, 1927: 319). Переживання, втілене у вираженні, як слово, підтверджене вчинком, дозволяє нам говорити про своєрідний «комплекс впливу» - Wirkungszusammenhang (Dilthey, 2013: 79). У філософії В. Дільтея проглядаються також зв’язки з діалектикою Гегеля, вираженою тут за допомогою понять пояснення і розуміння: «Природу ми пояснюємо, духовне життя - розуміємо» (Dilthey, 1927: 144). Від переживань, природно викликаних у нас, через вираження ми переходимо до розуміння і споглядаємо об'єкт пізнання на основі загальнокультурного досвіду. Такі розмірковування дають підстави стверджувати про інтерсуб'єктивність художньої картини світу й «об'єктивний дух» творів (термін, який В. Дільтей позичає у Ф. Гегеля, перетворюючи його у нове різностороннє поняття). Твір мистецтва, хоч і створюється окремим суб'єктом, виражає однак «не внутрішні процеси поета, а створений у них, але відокремлений від них взаємозв'язок» (Dilthey, 2013: 85). «... кожен твір мистецтва і кожен історичний вчинок зрозумілий лише тому, що вираження поєднується з розумінням завдяки спільності між ними. 
Окрема людина переживає, думає і діє постійно у сфері спільностей, і лише у ній вона приходить до розуміння» (Dilthey, 2013: 146-147).

Своєрідне бачення інтерпретації твору й художнього світу у ньому мали представники формальної школи початку XX ст. Літературознавці орієнтувались на лінгвістику і відштовхувалися від теорії Потебні - брали іiі за основу своїх суджень чи критикували й обгрунтовували власні наукові позиції. Головним гаслом формалістів було звільнення від впливів філософських і релігійних течій, під яким перебували їхні попередники критики-символісти, відмова від інтерпретації літературних фактів з погляду психології чи естетики. Вони працювали з фактами мистецтва, з конкретними літературно оформленими явищами гуманітарних наук. О. Потебня у своїх спостереженнях розмірковував про образність поезії і вважав, що поезія - це «мислення образами», а отже, без образів не існує мистецтва. Формалісти категорично заперечували це судження: «Поетична мова не $\epsilon$ лише мовою «образів»... звуки в поемі зовсім не $\epsilon$ виключно елементами зовнішньої милозвучності..., а мають самостійне значення» (Эйхенбаум, 1927: 6). Так стверджує один з представників цієї літературознавчої школи В. Шкловський, дослідження якого мали вирішальне значення в теорії літератури модернізму. «Образи дані, і в поезії набагато більше спогадів про образи, ніж мислення ними. Образне мислення не є ... тим, що об'єднує всі види мистецтва» (Шкловский, 1929: 9). Що саме мав на увазі науковець та як відбувається процес художнього сприйняття світу, який згодом відтворюється автором у художній картині світу, розглянемо детальніше далі.

У своїй праці «Воскресіння слова» В. Шкловський описав принцип відчутності форми як специфічну ознаку художнього сприйняття: «Ми не переживаємо звичне, не бачимо, а пізнаємо його. Ми не бачимо стін будинку, <..> не можемо змусити себе побачити, прочитати, а не "впізнати" звичне слово... "художне" сприйняття - це таке сприйняття, при якому переживається форма» (Шкловский, 1990: 35). У даному контексті «сприйняття» буде фігурувати не як психологічне поняття, властиве кожній людині, а як елемент 
мистецтва, що не існує поза його межами. Пережити, відчути форму художнього твору можливо лише за допомогою особливих художніх прийомів. Тобто, форма постає тут у новому, відмінному від потебнянського, значенні - як щось конкретно-динамічне, змістовне саме по собі. Текстуально виражений художніми прийомами зміст твору, який фактично відображає художню картину світу, формалісти вбачали саме крізь форму. Форма твору, основними компонентами якої $\epsilon$ предметний світ, художня мова й композиція, дозволяє нам чітко окреслити і описати художню картину поетичного чи прозового твору, а крізь неї і концепцію людини у світі. Отож, спираючись на методологічні підходи О. Потебні, ми розмірковували про «омовлений» художній світ, а завдяки формальному методу перед нами вже постає «оформлений» динамічний художній світ.

Варто звернути увагу також на відомий літературний прийом очуження, який досліджували формалісти і який є важливим у процесі пізнання художнього світу. Прийом полягає у відмові від автоматизму під час сприйняття літературного твору. Образ твору має не наблизити значення до нашого розуміння, а створити особливий спосіб «його сприйняття» - художній, дати відчуття речі як бачення, а не як упізнавання, по-новому поглянути на річ, щоб врешті іiі побачити. «Мистецтво - це спосіб пережити творіння речі, а створене у мистецтві неважливе», (Шкловский, 1929: 13) - вважав В. Шкловський, для якого, очевидно, процес творення був важливішим за його результат - художній твір. Саме під час створення предметів літературного мистецтва автор, використовуючи різноманітні художні прийоми, формує художню картину світу, яка підводить нас до нового способу сприйняття об'єктів дійсності, визначає динаміку подій створюваного художником світу. (Шкловский, 1929)

Є.М. Мелетинський, засновник дослідницької школи теоретичної фольклористики, написав низку праць, актуальних в контексті сьогоднішньої науки про літературу. Серед них і «Поетика міфу», яка дає грунтовні відомості про дві гілки міфологічної школи: ритуально-міфологічну та символічну (логіко-семантичну). Одним 3 представників ритуально-міфологічної школи був Нортроп Фрай, 
канадський філолог і дослідник міфології, який вважав, зокрема, що літературознавець дивиться на Шекспіра 3 певної відстані так само, як глядач споглядає картину художника. Погляд на твір 3 різних точок зору допомагає ясніше побачити головне у ньому - міфи й архетипи, приховані за «нафарбованою реальністю». Отже, Н. Фрай бачив у підгрунті художньої картини світу такі феномени, як міф, ритуал і архетип. Він розділяв їх на дві єдності: міфу і ритуалу, міфу й архетипу, визначаючи міф як розповідь, архетип як значення, ритуал - як дійство. Розуміння твору, закодоване у картині, починається $з$ побудови розповіді навколо певного стану свідомості. Міф $є$ центральною силою, що повідомляє архетипне значення ритуалові й пророчим, епіфанічним моментам, які для Фрая були вкрай важливими в контексті тлумачення трьох родів літератури. Ритуал був основою для драми, а пророчо-епіфанічні моменти або сни - для епосу і лірики.

Канадський науковець у своїх дослідженнях висував думку про те, що поетичні, у ширшому розумінні художні, ритми тісно пов'язані з природнім циклом через синхронізацію організму з природними ритмами, наприклад з сонячним роком. Це дозволяє знову ж таки акцентувати взаємозв'язок природної і художньої картин світу. Н. Фрай виділяв чотири фази життя природи стосовно певних міфів і архетипів образів та жанрів. Їх можна співвіднести, у свою чергу, з чотирма різними картинами світу, які відображають окремі жанри літератури. Наприклад, міф весни є прототипом комедії, міф літа - рицарського роману, міф осені тотожний з трагедією, а міф зими є архетипом іронії / сатири.

Як відомо, фундаментальною формою процесу світобуття є циклічний рух: життя - смерть. Природні цикли не лише перегукуються 3 циклами життя індивідів, а й безпосередньо впливають на них, що дзеркально відбивається у діяннях і творіннях людей. Відповідно й міфологізована картина світу теж є циклічною: життя, яке зароджується $з$ міфом весни, - народження героя, пробудження і воскресіння, розквіт життя у міфі літа - весілля, шлюб, тріумф, сімейна ідилія, захід сонця, смерть і падіння героїв у міфі осені, темрява, морок, 
безвихідність і всепануючий хаос у міфі зими. Кожен міф має свій неповторний колорит, що притягує зацікавлені погляди як звичайних читачів, так і фахівців у галузі культури і науки (Мелетинский, 2000). Вчений писав, що «завдання мистецтва - вирішення подібних антонімій і антитез, реалізація світу, в якому збігаються внутрішні бажання (авторський художній світ - прим. А.Л.) і зовнішні обставини (природній світ - прим. А.Л.)» (Мелетинский, 2000: 110).

«Міф - це не лише матеріал, з якого розвивається література < ..>, міфопоетична здібність $\epsilon$ частиною мисленнєвого процесу, яка відповідає певним потребам людини, міф доставляє уявлення та зразки для письменника i для критика» (Мелетинский, 2000: 114). Отже, беззаперечним є твердження, що художня картина світу (суб'єктивна і об'єктивна водночас, адже твориться автором на тлі багатовікової історії народу) постає з міфологічної картини образного світу природи, яку художник споглядає, пізнає і відтворює у своїй індивідуальній манері.

\section{Висновки}

Художній світ - це світ об'єктивних образів і суб'єктивних значень, фіктивний світ, що репрезентує реальність, яку ми пізнаємо. Пізнати художню дійсність можливо, пройшовши крізь багатогранну форму художнього твору і знайшовши в поетичних образах відгомін минулого досвіду. Це змушує нас знову і знову переживати відоме та відроджувати вічні істини людського буття. Художня картина світу як наукове поняття піддається теоретичному моделюванню з позиції літературознавчої науки, яка розробляє нові вектори наукової ії інтерпретації, що сприяє розумінню феномену людини у цьому світі.

\section{Література}

Дильтей, В. (2000). Введение в науки о духе. А.В. Михайлова, Н.С. Плотников (Ред.). Собрание сочинений (Т. 1). Москва: Дом интеллектуальной книги.

Мелетинский, Е.М. (2000). Поэтика мифа (3-е изд., репринтное). Москва: Издательская фирма Восточная литература. 
120 Наукові записки ХНПУ ім. Г.С. Сковороди. Літературознавство, 2020, вип. 1(95)

Потебня, А.А. (1905). Из записок по теории словесности. Поэзия и проза. Тропы и фигуры. Мышление поэтическое и мифическое. Харьков: Изд. М.В. Потебни.

Потебня, А.А. (1990). Теоретическая поэтика. А.Б. Муратов (Сост., вступ. ст., коммент.). Москва: Высшая школа.

Фізер, І. (1996). Психолінгвістична теорія літератури Олександра Потебні: Метакритичне дослідження [Psycholinguistic theory of literature by Alexander Potebny: Metacritical research]. I. Дзюба (Передм.). Київ: АТ Обереги.

Шкловский, В.Б. (1990). Гамбургский счет. А.Ю. Галушкина \& А.П. Чудакова (Ред.), Воскрешение слова (с. 35-42). Москва: Советский писатель.

Шкловский, В. (1929). О теории прозы. Москва: Федерация.

Эйхенбаум, Б.М. (1927). Теория формального метода. Сборник статей Эйхенбаума. Литература: Теория. Критика. Полемика, 116-148. Режим доступа: http://www.opojaz.ru/method/method_intro.html

Dilthey, W. (1927). Einleitung in die Philosophie des Lebens. Gesammelte Schriften (Bd. 5). Leipzig und Berlin: Teubner.

Dilthey, W. (2013). Der Aufbau der geschichtlichen Welt in den Geisteswissenschaften. Gesammelte Schriften (Bd. 7). Berliner Ausgabe.

Humboldt, W. (1907). Rezension von Goethes Zweiter römischer Aufenthalt. Gesammelte Schriften (Vol. 6). Berlin.

Humboldt, W. (1836). Über die Verschiedenheit des menschlichen Sprachbaues und ihren Einfluss auf die geistige Entwicklung des Menschengeschlechts. Berlin.

Müller, M. (1875, 1870). Vorlesungen über die Wissenschaft der Sprache (1. Serie von 9 Vorlesungen). Leipzig (2. Serie von 12 Vorlesungen). Leipzig.

\section{References}

Dil'tej, V. (2000). Vvedenie v nauki o duhe [Introduction to the science of the spirit]. A.V. Mihajlova, N.S. Plotnikov (Ed.). Sobranie sochinenij (Vol. 1). Moskva: Dom intellektual'noj knigi [in Russian].

Meletinskij, E.M. (2000). Pojetika mifa. (3-rd ed., reprint). Moskva: Izdatel'skaja firma Vostochnaja literatura [in Russian].

Potebnja, A.A. (1905). Iz zapisok po teorii slovesnosti. Pojezija i proza. Tropy i figury. Myshlenie pojeticheskoe i mificheskoe [From notes on the theory 
of literature. Poetry and prose. Trails and figures. Thinking is poetic and mythical]. Har'kov: Izd. M.V. Potebni [in Russian].

Potebnja, A.A. (1990). Teoreticheskaja pojetika [The poetics of myth]. A. B. Muratov (Ed.). Moskva: Vysshaja shkola [in Russian].

Fizer, I. (1996). Psykholinhvistychna teoriia literatury Oleksandra Potebni: Metakrytychne doslidzhennia. I. Dziuba (Ed.). Kyiv: AT «Oberehy» [in Ukrainian].

Shklovskij, V.B. (1990) Gamburgskij schet [Hamburg account]. A.Ju. Galushkina \& A.P. Chudakova (Red.), Voskreshenie slova (s. 36-42). Moskva: Sovetskij pisatel'.

Shklovskij, V. (1929). O teorii prozy. Moskva: Izdatel'stvo «Federacija» [in Russian].

Jejhenbaum, B.M. (1927). Teorija formal'nogo metoda [Theory of the formal method]. Sbornik statej Jejhenbauma. Literatura: Teorija. Kritika. Polemika [Collection of articles by Eichenbaum. Literature: Theory. Criticism. Controversy], 116-148. Retrieved from http://www.opojaz. $\mathrm{ru} / \mathrm{method} /$ method_intro.html

Dilthey, W. (1927). Einleitung in die Philosophie des Lebens. Gesammelte Schriften (Bd. 5) Leipzig und Berlin: Teubner.

Dilthey, W. (2013). Der Aufbau der geschichtlichen Welt in den Geisteswissenschaften. Gesammelte Schriften (Bd. 7). Berliner Ausgabe. Humboldt, W. (1907). Rezension von Goethes Zweiter römischer Aufenthalt. Gesammelte Schriften. (Vol. 6). Berlin.

Humboldt, W. (1836). Über die Verschiedenheit des menschlichen Sprachbaues und ihren Einfluss auf die geistige Entwicklung des Menschengeschlechts. Berlin.

Müller, M. (1875, 1870). Vorlesungen über die Wissenschaft der Sprache (1. Serie von 9 Vorlesungen). Leipzig. (2. Serie von 12 Vorlesungen). Leipzig.

\section{Анотація}

\section{А.О. Ліпісівіцька. Художня картина світу: постанова проблеми на перетині методологічних площин}

Художня картина світу є особливим авторським баченням навколишнього світу, реалізованим на сторінках певного художнього твору. Вона дозволяє нам розтлумачити сутність людського буття, приховану за численними образами і персонажами уявного світу, що співвідноситься з існуючим. У 
поданій статті ми намагаємося теоретично розглянути поняття «художня картина світу» 3 позицій різних літературознавчих методологій.

Спираючись на спостереження відомого українського науковця О.О. Потебні, ми пов'язуємо художню картину світу із зовнішньою та внутрішньою формою тексту, а також значенням, заданим головними інтенціями художнього твору. Саме таким шляхом - через зовнішню форму, внутрішню форму, значення (зміст) - рухається людська свідомість у процесі пізнання сутності об'єктів художньої дійсності. Художнє пізнання можливе завдяки образному світу мови, поринувши у який можна відшукати всі першопочаткові значення і смисли, породжені процесами омовлення/висловлення. Німецький філософ Вільгельм Дільтей зобразив процес пізнання художнього світу у вигляді піраміди зіставних із потебнянськими понять переживання - вираження - розуміння. Асоціації, які виникають у реципієнта під час споглядання об'єкту художнього світу, виражаються інтерсуб'єктивними артикуляціями, і саме цей взаємозв'язок є зображенням художньої картини світу, за якою приховані культурні смисли певного народу. Представники формальної літературознавчої школи стверджували, що побудова художньої картини світу і процес пізнання об'єктів реальності відбувається завдяки відчутності форми, поза якою твір мистецтва не існує. Важливим аспектом аналізу й інтерпретації художньої картини світу $є$ також міфологічність літературного твору. Кожен образ, за яким приховане висхідне значення пізнаваного об'єкту, відтворює певний міф - розповідь про дійсну реальність природного світу, що існує у просторі світу мистецтва.

Художня картина світу як наукове поняття піддається теоретичному моделюванню з позиції літературознавчої науки, яка розробляє нові вектори наукової інтерпретації художнього бачення світу, створюваного автором, та розуміння феномену людини у цьому світі.

Ключові слова: художня картина світу, літературознавча методологія, форма, зміст, художнє пізнання, О. Потебня, В. Дільтей, формальна школа.

\section{Аннотация}

\section{Липисивицкая А.О. Художественная картина мира: постановка} проблемы на пересечении методологических плоскостей

Художественная картина мира - это особенное авторское видение окружающего мира, реализованное на страницах художественного произведения. Она позволяет нам интерпретировать сущность человеческого бытия, скрытую за многочисленными образами и персонажами воображаемого 
мира, который соотносится с существующим миром. В данной статье мы пытаемся теоретически рассмотреть понятие «художественная картина мира» с позиций разных литературоведческих методологий.

Опираясь на теоретические идеи известного украинского ученого А.А. Потебни, художественную картину мира можно связать с внешней и внутренней формой текста, а также значением, заданным главными интенциями литературного произведения. Именно таким путём - через внешнюю форму, внутреннюю форму, значение (содержание) - движется человеческое сознание в процессе познания сущности объектов художественной действительности. Художественное познание возможно благодаря образному миру языка, окунувшись в который можно отыскать все первоначальные значения и смыслы, порожденные процессами вербализации/высказывания. Немецкий философ Вильгельм Дильтей изобразил процесс познания художественного мира в виде пирамиды сопоставимых с потебнянскими понятий переживания - выражения - понимания. Ассоциации, которые возникают у реципиента во время созерцания объекта художественного мира, выражаются интерсубъективными артикуляциями, и именно эта взаимосвязь является изображением картины художественного мира, за которой скрыты культурные смыслы определённого народа. Представители формальной школы утверждали, что построение художественной картины мира и процесс познания объектов реальности происходит благодаря ощутимости формы, за пределами которой произведение искусства не существует. Важным аспектом анализа и интерпретации художественной картины мира является также мифологичность литературного произведения. Каждый образ, за которым скрыто исходное значение познаваемого объекта, воспроизводит некоторый миф - рассказ о действительной реальности естественного мира, которая существует в пространстве мира искусства.

Художественная картина мира как научное понятие теоретически моделируется с позиции литературоведческой методологии, которая, в свою очередь, представляет новые векторы научной интерпретации художественного видения мира, создаваемого автором, и понимания феномена человека в этом мире.

Ключевые слова: художественная картина мира, литературоведческая методология, форма, содержание, художественное познание, А. Потебня, В. Дильтей, формальная школа. 


\section{Abstract \\ A.O. Lipisivitska. Artistic picture of the world: problem statement at the intersection of methodological planes}

The artistic picture of the world is a special author's vision of the world around us, realized in a work of art. It allows us to interpret the essence of human existence, hidden behind numerous images and characters of the imaginary world, which is correlated with the existing one. In this article the concept of the «artistic picture of the world» is theoretically considered from the standpoint of various literary methodologies.

Based on the thoughts of the famous Ukrainian scientist A.A. Potebnya, the artistic picture of the world is associated with the external and internal form of the text, as well as the meaning conveyed by the main intentions of a literary work. This way - through the external form, internal form, meaning (content) the human consciousness cognizes the essence of the artistic objects. Artistic cognition is possible due to the imaginative world of the language, plunging into which you can find all the original meanings and senses generated by the process of verbalization / utterance. The German philosopher Wilhelm Dilthey reflected the process of cognition of the artistic world in the form of a pyramid which is comparable to the concepts developed by Potebnya and includes experience-expression - understanding. Associations that arise in the recipient during the contemplation of the object of the artistic world are expressed by intersubjective articulations, and this interrelation is an image of the picture of the artistic world, behind which the cultural senses of a certain nation are hidden. Representatives of the formal school argued that the construction of the artistic picture of the world and the process of cognition of the objects of reality is due to the perceptibility of form, beyond which a work of art does not exist. An important aspect of the analysis and the interpretation of the artistic picture of the world is the mythological character of a literary work. Each image, behind which the initial meaning of the cognizable object is hidden, reproduces a certain myth - a story about the concrete reality of the natural world that exists within the art world.

The artistic picture of the world as a scientific concept is theoretically modeled from the position of literary methodology that represents new vectors of scientific interpretation of the artistic vision of the world, created by the author, and understanding of the human phenomenon in this world.

Key words: artistic picture of the world, literary methodology, form, content, artistic cognition, A. Potebnya, W. Dilthey, formal school. 
Рукопис статті отримано 24 лютого 2020

Рукопис затверджено до публікації 15 квітня 2020

\section{Інформація про автора}

Ліпісівіцька Аліна Олексіївна - аспірант кафедри германської філології та зарубіжної літератури ННІ іноземної філології Житомирського державного університету імені Івана Франка; вул. Велика Бердичівська, 40 м. Житомир, Україна, 10008; e-mail: alinkahdl@gmail.com; https:/orcid. org/0000-0003-4772-3671 